\title{
PENGARUH PERSEPSI PESERTA DIDIK MENGENAI MEDIA SOSIAL TERHADAP SIKAP TOLERANSI
}

\author{
Surati \\ Fakultas Keguruan dan Ilmu Pendidikan, Universitas Pamulang \\ surati.wsb@gmail.com \\ Ichwani Siti Utami \\ Fakultas Keguruan dan Ilmu Pendidikan, Universitas Pamulang \\ amiutami10@gmail.com
}

Naskah diterima: 20 Maret 2018, review: 23 Maret 2018, revisi: 27 Maret 2018, disetujui: 31 Maret 2018.

\begin{abstract}
Abstrak
Belakangan ini, media sosial berkembang semakin masif dan digunakan oleh semua kalangan mulai dari anak-anak, remaja, hingga orang dewasa. Kehadirannya, telah mempengaruhi aktivitas, sikap, dan perilaku manusia. Penelitian ini bertujuan untuk menguji secara empiris pengaruh persepsi peserta didik mengenai media sosial terhadap sikap toleransi dengan studi korelasi di SMA Bakti Idhata Cilandak Jakarta Selatan. Metode penelitian yang digunakan dalam penelitian ini menggunakan metode survei melalui analisis korelasi yakni melihat variabel-variabel yang akan diteliti. Hasil penelitian menemukan bahwa tidak ada pengaruh yang positif dan signifikan antara persepsi peserta didik mengenai media sosial terhadap sikap toleransi. Maka, dapat diinterpretasikan bahwa perubahan pada sikap toleransi tidak terpengaruh dari persepsi peserta didik mengenai media sosial.
\end{abstract}

Kata-kata kunci: persepsi peserta didik, media sosial, sikap toleransi

\author{
Jurnal Pendidikan Kewarganegaraan \\ Journal of Civics and Education Studies \\ The journal is published by Department of Civic Education \\ Faculty of Teacher Training and Education \\ Universitas Pamulang - Indonesia
}

Copyright (C) 2018 / ISSN: 2302-0865 


\section{PENDAHULUAN}

Pendidikan adalah usaha sadar dalam mempersiapkan generasi muda yang intelek dan bekepribadian baik. Pendidikan tidak hanya mengembangkan dari segi pengetahuan saja melainkan harus mampu mengembangkan karakter siswa didiknya. Pendidikan pengembangan karakter dapat dilakukan melalui berbagai macam kegiatan, seperti penanaman nilai, pengembangan budi pekerti, nilai agama, pembelajaran dan pelatihan nilai- nilai moral dan lainlain.

Sebagaimana digariskan dalam Pasal 3 Undang-Undang Republik Indonesia Nomor 20 Tahun 2003 tentang Sistem Pendidikan Nasional (Sisdiknas) yaitu: Pendidikan nasional berfungsi mengembang-kan kemampuan dan membentuk karakter serta peradaban bangsa yang bermartabat dalam rangka mencerdaskan kehidupan bangsa, bertujuan untuk mengembangkan potensi peserta didik agar menjadi manusia yang beriman dan bertakwa kepadaTuhan Yang Maha Esa, berakhlak mulia, sehat, berilmu, cakap, kreatif, mandiri, dan menjadi warga negara yang demokratis serta bertanggung jawab.

Pada bidang pendidikan masalah yang dihadapi adalah berlangsungnya pendidikan yang kurang bermakna bagi pengembangan pribadi dan watak peserta didik, yang berakibat hilangnya kepribadian dan kesadaran akan makna hakiki kehidupan. Mata pelajaran yang berorientasi akhlak dan moralitas dan agama kurang diberikan dalam bentuk latihan-latihan pengamalan untuk menjadi corak kehidupan sehari-hari. Karenanya masyarakat cenderung tidak memiliki kepekaan yang cukup untuk membangun toleransi dan kebersamaan, khususnya dengan menyadari keberadaan masyarakat yang majemuk.

Tabel 1. Hasil Survei Awal

\begin{tabular}{|c|c|c|c|c|c|}
\hline $\begin{array}{c}\text { INDI- } \\
\text { KATOR }\end{array}$ & SS & $S$ & KS & TS & STS \\
\hline $\begin{array}{l}\text { Sikap } \\
\text { toleransi } \\
\text { merupakan } \\
\text { reaksi untuk } \\
\text { menyesuaik } \\
\text { an diri } \\
\text { dalam } \\
\text { menghadapi } \\
\text { pluralitas. }\end{array}$ & 53 & 65 & 60 & 64 & 58 \\
\hline $\begin{array}{l}\text { Sikap } \\
\text { toleransi } \\
\text { dilihat dari } \\
\text { pandangan } \\
\text { seseorang } \\
\text { terhadap } \\
\text { peristiwa } \\
\text { dan } \\
\text { perbedaan } \\
\text { pendapat } \\
\text { orang lain. }\end{array}$ & 47 & 58 & 77 & 53 & 65 \\
\hline $\begin{array}{l}\text { Sikap } \\
\text { toleransi } \\
\text { merupakan } \\
\text { proses } \\
\text { kognitf, } \\
\text { afektif dan } \\
\text { psikomotori } \\
\text { k dalam } \\
\text { menghadapi } \\
\text { pluralitas. }\end{array}$ & 53 & 48 & 70 & 63 & 66 \\
\hline $\begin{array}{l}\text { Sikap } \\
\text { toleransi } \\
\text { merupakan } \\
\text { bentuk } \\
\text { penyesuaian } \\
\text { diri }\end{array}$ & 36 & 47 & 67 & 78 & 72 \\
\hline
\end{tabular}




\begin{tabular}{llllll}
\hline $\begin{array}{l}\text { terhadap } \\
\text { masyarakat } \\
\text { majemuk. }\end{array}$ & & & & & \\
\hline JUMLAH & 189 & 218 & 274 & 258 & 261 \\
\hline$\%$ & 15,8 & 18,2 & 22,8 & 21,5 & 21,8 \\
\hline
\end{tabular}

Berdasarkan tabel diatas maka dapat kita ketahui bahwa hasil analisis data survei yang dilakukan di kelas X SMA Bakti Idhata menunjukkan sikap toleransi yang rendah. Dari survey yang disebar kepada 30 reponden peserta didik 21,8\% menjawab Sangat Tidak Setuju (STS), 21,5\% menjawab Tidak Setuju (TS), $22,8 \%$ menjawab Kurang Setuju (KS), $18,2 \%$ menjawab tidak Setuju (S), dan $15,8 \%$ menjawab Sangat Setuju (SS). Artinya kesadaran dalam toleransi pada peserta didik di kelas $\mathrm{X}$ tergolong rendah. Hal tersebut ditunjukan dari pengamatan yang dilakukan di kelas $\mathrm{X}$.

Ada beberapa permasalahan sosial yang dilakukan oleh peserta didik, seperti pada saat berlangsungnya kegiatan belajar-mengajar terutama ketika guru memberikan tugas secara langsung mengenai contoh permasalahan dalam peradilan di Indonesia, tidak sedikit peserta didik mengajukan pendapat dengan cara yang tidak baik yang dapat menyinggung perasaan teman sekelasnya, seperti mengolok fisik seorang etnis sebagai bahan bulliying dikelas, menirukan logat bahasa sebagai bahan candaan agar dapat ditertawakan oleh teman sekelasnya, bahkan menyebut teman sekelasnya dengan sebutan tokoh pejabat yang korup atau yang tersandung kasus sebagai olok-olokan di kelas.
Sebagai guru sepatutnya merasa sangat khawatir dan menegur secara lisan sikap peserta didik yang tidak baik bahkan menurunkan nilai sikap sebagai hukuman agar peserta didik merasa kapok dan tidak mengulanginya lagi. Namun ternyata bagi sebagian besar peserta didik candaancandaan tersebut sudah dinilai sangat biasa sebagai cara dalam berkomunikasi agar dianggap tidak kaku yang diikuti dari perkembangan informasi yang didapat dari internet dan media sosial. Hal tersebut memberikan dampak negatif terhadap peserta didik seperti munculnya sikap kebencian antar peserta didik, sikap mengucilkan dan merendahkan antar peserta didik, bahkan muncul geng-geng antar peserta didik yang rawan akan terjadinya konflik.

Padahal dalam lingkungan sekolah sikap toleransi menjadi nilai yang penting dan mendasar untuk dikembangkan dan dilakukan dalam kehidupan sehari-hari termasuk dilingkungan sekolah. Perubahan-perubahan yang terjadi dalam berbagai aspek kehidupan sebagai dampak langsung atau tidak langsung dari kemajuan ilmu pengetahuan dan teknologi telah merasuk ke dalam sisi kehidupan individu dan masyarakat. Dampak dari suatu perubahan tersebut disadari atau tidak disadari seringkali juga menyebabkan terjadinya pengikisan nilainilai positif dalam kehidupan individu dan masyarakat. Salah satu bentuk nilai positif yang sangat rentan terhadap pengaruh-pengaruh nilai-nilai luar adalah nilai-nilai toleransi. 
Namun arus modernisasi yang seringkali secara gegabah dinilai sebagai suatu yang lebih baik semakin menggeser nilai-nilai yang sangat luhur ini. Dampaknya lebih jauh persatuan dan kesatuan menjadi pudar, sikap toleransi menjadi sesuatu yang tidak memiliki nilai yang diagungkan lagi. Dalam keadaan ini konflik tidak bias dihindari, bahkan cenderung semakin meluas dan melebar dalam berbagai bentuknya.

Belakangan ini situs jejaring sosial sangat marak perkembangannya di sekitar kita. Bahkan penggunanya sangat banyak dan meliputi hampir berbagai kalangan usia mulai dari anak-anak, remaja, dan orang dewasa. Namun saat ini seiring dengan perkembangannya, internet mampu melahirkan suatu jaringan baru yang biasa dikenal dengan sebutan media sosial. Sebagaimana yang diketahui, media sosial merupakan salah satu media online dimana para penggunanya dapat ikut serta dalam mencari informasi, berkomunikasi, dan menjaring pertemanan, dengan segala fasilitas dan aplikasi yang dimilikinya seperti blog, facebook, twitter, instagram, dan masih banyak lainnya. Kehadiran media sosial telah membawa pengaruh tersendiri terhadap kegiatan yang dilakukan oleh manusia saat ini.

Menurut C. Widyo Hermawan adanya penggunaan internet melaui media sosial, telah menghadirkan sebuah web forum yang dapat membentuk suatu komunitas online. Layaknya forum diskusi, sebuah web forum juga dapat menampung ide, pendapat dan segala informasi dari para anggotanya sehingga dapat saling berkomunikasi atau bertukar pikiran antara satu sama lainnya. Pada dasarnya, forum online merupakan sebuah papan pengumuman yang tersedia dalam bentuk online. Namun seiring berjalannya waktu sebuah forum online mengalami perluasan fungsi, yaitu tidak hanya sekedar berbagi informasi melainkan sebagai sarana akomodasi antar sesama pengguna dan pihak yang memiliki forum tersebut. Pada awalnya media sosial isinya lebih terkait hal-hal yang sifatnya fun dan nostalgia ria tapi selanjutnyaterjadi perkembangan yang mengarah ke arah profesionalisme.

Dari sekedar komunitas biasa, lalu bertransformasi menjadi tempat untuk melakukan kontak bisnis atau komunitas yang lebih serius. Para pengguna ini mulai memanfaatkan media sosial sebagai alat yang mendukung profesi ataupun wirausaha. Para pengguna media sosial pun mulai bergeser, tidak hanya didominasi oleh generasi muda, serta golongan tua seperti pejabat pemerintahan sudah mulai menggunakan media sosial sebagai tempat favorit untuk bersosialisasi.

Menurut Ali dan Syamsudin, media sosial telah memberikan dampak terhadap penglibatan masyarakat dalam isu sosial. Penglibatan ini meliputi aktif mengikuti perkembangan isu dalam blog online, dengan cara membentuk online group untuk menyampaikan aspirasi, membuat akun blog tentang isu sosial, memberi komen dalam berita online, artikel, dan mengambil bagian dalam diskusi online, serta menyebar luaskan berita yang berkaitan dengan isu sosial. Ada banyak motif yang mendorong seseorang menggunakan media, Menurut Katz dan 
Blummer mendiskiripsikan mengenai motif penggunaan media, diantaranya ada kebutuhan kognitif (kebutuhan akan informasi, pengetahuan dan pemahaman), kebutuhan afektif (kebutuhan akan emosi, perasaan dan kesenangan), kebutuhan integratif personal (kebutuhan akan kredibilitas, stabilitas dan status, kebutuhan integratif sosial (kebutuhan akan interaksi dengan teman atau keluarga), dan kebutuhan pelepas ketegangan (kebutuhan akan hiburan).

Boyd dan Ellison mendiskripsikan mengenai karakteristrik media sosial sebagai sebuah web yang memiliki fitur yang memungkinkan seseorang untuk mengkonstruksi sebuah profil publik, berbagi pengetahuan kepada teman dan melihat teman yang ada dalam daftar koneksinya, dan semua hal tersebut dilakukan melalui sistem. Media sosial telah menjadi jembatan untuk membangun jaringan komunikasi antarpersonal. Melalui profil, aktivitas yang diungkapkan pengguna menjadi jalan untuk mereka berkomunikasi, misalnya saling memberikan komentar pada foto ataupun status yang diunggah pengguna media sosial.

Menurut Tovler, setiap jenis teknologi, melahirkan lingkungan teknologi. Lingkungan teknologi ini secara tidak langsung merubah kebudayaan, norma-norma sosial, pola-pola interaksi, dan organisasi-organisasi masyarakat. ${ }^{5}$ Ungkapan ini secara tidak langsung menjelaskan ungkapan McLuhan mengenai hubungan antara teknologi, media, dan masyarakat atau yang sering disebut dengan tehnological determinsm, yaitu paham bahwa teknologi bersifat determinan atau menentukan dalam membentuk kehidupan manusia.

Pemikiran McLuhan ini sering dinamakan teori mengenai ekologi media, dimana melihat lingkungan media, gagasan bahwa teknologi dan teknik, mode informasi dan kode komunikasi yang memainkan peran penting dalam kehidupan manusia. Asumsi dari teori ekologi media, yaitu:

1. Media mempengaruhi setiap perbuatan atau tindakan dalam masyarakat. Asumsi pertama ini menekankan pada gagasan pada saat ini manusia tidak dapat lepas dari media.

2. Media merupakan sebuah hal yang penting, bahkan menembus ke dalam kehidupan manusia yang paling dalam. Keberadaan media memberikan pengaruh dalam kehidupan manusia dan masyarakat.

3. Media memperbaiki persepsi dan mengelola pengalaman. Asumsi kedua ini menjelaskan bagaimana manusia Secara langsung dipengaruhi media. Dimana media memiliki kekuatan besar dalam mempengaruhi padangan kita terhadap dunia.

4. Media mengikat dunia bersama-sama. Asumsi ketiga dari teori ekologi media menyebutkan bahwa media mengikat dunia bersama-sama. Menjelaskan bagaimanamedia mengik at dunia menjadi satu system politik, ekonomi, sosial, dan budaya global, atau yang disebut dengan global village. 
Kehadiran teknologi memberikan pengaruh sangat besar dalam kehidupan manusia. Manusia memiliki hubungan simbolik dengan teknologi, dimana kita menciptakan teknologi dan kemudian teknologi kembali pada siapa diri kita. Menurut McLuhan, teknologi media telah menciptakan revolusi di tengah masyarakat karena masyarakat pada saat ini sudah sangat tergantung kepada teknologi dan tatanan masyarakat terbentuk berdasarkan pada kemampuan masyarakat menggunakan teknologi. Teknologi komunikasi menjadi penyebab utama perubahan budaya. Morissan menyatakan bahwa media merupakan kepanjangan atau eksistensi dari pikiran manusia, dengan demikian media memegang peran dominan dalam mempengaruhi tahapan perkembangan manusia.

Berkembangnya teknologi informasi terutama penggunaan media sosial dikalangan peserta didik merupakan sesuatu yang tidak dapat dihindari lagi. Hampir setiap saat peserta didik mengakses media sosial hanya untuk sekedar mencari informasi. Fenomenafenomena yang marak beredar pada media sosial seperti instagram, youtube, facebook dan masih banyak lainnya, sering ditirukan dikalangan remaja dalam. Rendahnya sikap toleransi yang dilakukan oleh peserta didik salah satunya karena terpengaruh adanya fenomena sosial yang terdapat pada media sosial. Seperti dikatakan O’Brien Bungin, yang mengatakan bahwa perilaku manusia dan teknologi memiliki interaksi di dalam lingkungan sosioteknologi. Sehingga bisa dikatakan bahwa ketika IT hadir dalam bentuk yang baru, maka akan mempengaruhi struktur masyarakat, strategi komunikasi, masyarakat dan budaya, serta proses sosial.

Berdasarkan pendapat diatas dapat kita ketahui bahwa sikap toleransi dapat dipengaruhi oleh adanya perkembangan kemajuan ilmu pengetahuan dan teknologi, khususnya perkembangannya internet yang mampu melahirkan suatu jaringan baru yang dikenal dengan sebutan media sosial. Dan setiap teknologi melahirkan lingkungan teknologi yang secara tidak langsung merubah kebudayaan, norma-norma sosial, pola-pola interaksi, dan organisasiorganisasi masyarakat. Seperti dalam hal komunikasi media sosial dapat membentuk suatu komunitas web forum online yang memberikan dampak terhadap penglibatan masyarakat dalam isu sosial karena kemudahannya dalam memperoleh dan menyebarkan informasi.

Dalam lingkungan teknologi tersebut dapat mempengaruhi pemikiran dan tindakan seseorang. Kaitannya dengan sikap toleransi dikalangan peserta didik dapat dilihat secara nyata dari aktivitasaktivitas sosial yang dilakukan sehari-hari di lingkungan sekolah yang sering meniru dari perkembangan informasi dalam media sosial. Berdasarkan latar belakang di atas, maka penulis tertarik untuk membahas masalah persepsi peserta didik mengenai media sosial terhadap sikap toleransi. Pendidikan Kewarganegaraan sebagai satu mata pelajaran di sekolah saat ini harus lebih menekankan kepada pembentukan karakter,

dimana 
substansi pembelajarannya mulai mengarah pada bagaimana menjadikan warga negara yang mampu berpartisipasi secara efektif, cerdas, demokratis dan bertanggung jawab.

Pendidikan

Kewarganegaraan

diarahkan untuk mencapai dua sasaran pokok yang seimbang. Pertama meningkatkan pengetahuan dan keterampilan peserta didik tentang etika, moral, dan asas-asas dalam hidup berbangsa dan bernegara. Kedua, membentuk sikap, perilaku, dan kepribadian sesuai dengan nilai-nilai luhur bangsa Indonesia. Dalam hal penanaman karakter siswa khususnya sikap toleransi yang membuat peniliti tertarik untuk membahasnya lebih lanjut.

Hasil penelitian ini diharapkan memberikan sumbang asih pada peningkatan kualitas pendidikan. Pada segi teoritis, penelitian dapat bermanfaat; 1) untuk pengembangan ilmu pengetahuan khususnya mengetahui tentang persepsi peserta didik mengenai media sosial terhadap sikap toleransi; dan 2) Untuk memperkuat teori bahwa persepsi peserta didik mengenai media sosial terhadap sikap.

Secara prakitis penelitian dapat bermanfaat untuk; 1) memberi wawasan kepada peneliti tentang persepsi peserta didik mengenai media sosial terhadap sikap tolernsi; 2) memberikan informasi penting bagi guru sebagai bahan pertimbangan dalam melaksanakan pembelajaran dan meningkatkan kinerja guru; 3) sebagai acuan bagi sekolah untuk membiwa sikap peserta didik di lingkungan sekolah; 4) sebagai salah satu upaya bagi Universitas Pamulang untuk mengembangkan ilmu pengetahuan terkait sikap toleransi dalam pembelajaran Pendidikan Pancasila dan Kewarganegaraan (PPKn).

\section{METODE PENELITIAN}

Penelitian ini bertujuan untuk menganalisis data secara empiris pengaruh positif dan signifikan persepsi peserta didik mengenai media sosial terhadap sikap toleransi di SMA BAKTI IDHATA, Cilandak, Jakerta Selatan Tahun Ajar 2016/2017.

Metode penelitian yang digunakan dalam penelitian ini menggunakan metode survei melalui analisis korelasi yakni melihat variabel-variabel yang akan diteliti. Penelitian ini diharapkan dapat menemukan pengaruh persepsi peserta didik mengenai media sosial terhadap sikap toleransi.

Data disajikan dalam bentuk angkaangka atau data yang diangkat untuk memberikan gambaran ada tidaknya pengaruh antara variabel bebas dengan variabel terikat, variabel bebas dan variabel terikat dalam penelitian ini. Populasi target pada penelitian ini adalah seluruh peserta didik kelas X dan XI di SMA Bakti Idhata, Cilandak, Jakarta Selatan. Dikarenakan kelas XII sudah lulus ujian, maka tidak dicantumkan dalam populasi target. Jumlah siswa SMA Bakti Idhata 290 siswa. Populasi terjangkau dalam penelitian ini adalah peserta didik kelas X MIA 1, X MIA 2, X IIS 1 , dan $\mathrm{X}$ IIS $2, \mathrm{X}$ IIS 3 , dan $\mathrm{X}$ IIS 4 
SMA Bakti Idhata Cilandak, Jakarta Selatan, Tahun Ajaran 2016/2017.

Teknik yang digunakan dalam penelitian ini adalah Proporsional; Cluster Random Sampling yaitu dari jumlah populasi ditentukan jumlah sampel sebagai. Di dalam menentukan besarnya sampel penelitian menggunakan rumus solvin. Sampel dalam penelitian ini sebanyak 126 peserta didik pada kelas X MIA 1, X MIA 2, X IIS 1, dan X IIS 2, X IIS 3, dan $X$ IIS 4. Teknik pengumpulan data yang digunakan untuk mengumpulkan data tentang persepsi peserta didik mengenai media sosial terhadap sikap toleransi, yaitu dengan menggunakan angket.

\section{HASIL DAN PEMBAHASAN}

Hasil penelitian persepsi peserta didik mengenai media sosial diperoleh rentang nilai sebesar 65 dengan data tertinggi 173 dan data terendah 108, banyaknya kelas 8 , dengan panjang interval 8. Kemudian, diperoleh pula nilai rata-rata (mean) sebesar 131,07 nilai tengah (median) sebesar 125,28, nilai median sebesar 63, dan nilai modus sebesar 120,5. Dan simpangan baku sebesar 222,356. Hasil penelitian mengenai Sikap Toleransi diperoleh rentang data sebesar 78 dengan skor tertinggi 190 dan skor terendah 112 , banyak kelas 9, dengan panjang interval 8 . Kemudian, diperoleh pula nilai rata-rata (mean) sebesar 156,58, nilai tengah (median) sebesar 157,76, nilai modus sebesar 147,06, dan simpangan baku sebesar 296,613.

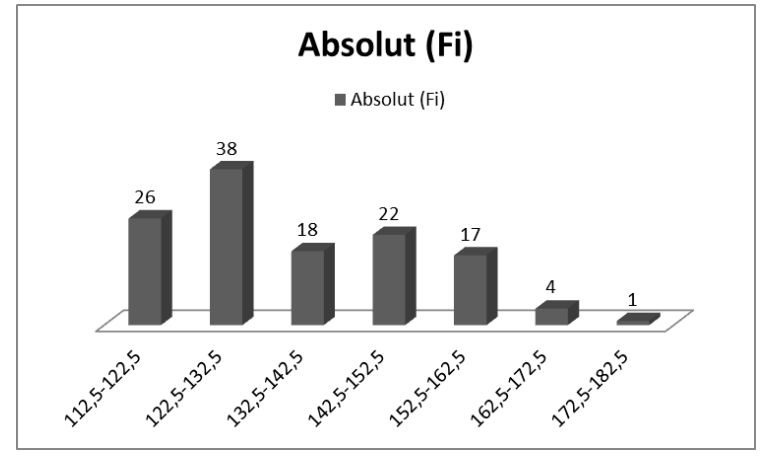

Grafik 1. Frekwensi Tertinggi Peserta Didik Mengenai Media Sosial

Dari grafik di atas dapat diperoleh informasi data yang menunjukkan frekuensi tertinggi persepsi peserta didik mengenai media sosial di SMA Bakti Idhata Cilandak, Jakarta Selatan terletak antara 122,5-132,5 dengan frekuensi 38 peserta didik sebesar $30 \%$. Rata-rata skor yang didapat peserta didik yaitu 131,07 terdapat pada interval 122,5-132,5. Adapun nilai modus atau nilai yang sering muncul yaitu 120,5. Artinya variabel persepsi peserta didik mengenai media sosial paling banyak diperoleh bernilai 120,5 .

Hasil penelitian mengenai Sikap Toleransi diperoleh rentang data sebesar 78 dengan skor tertinggi 190 dan skor terendah 112, banyak kelas 9, dengan panjang interval 8. Kemudian, diperoleh pula nilai rata-rata (mean) sebesar 156,58, nilai tengah (median) sebesar 157,76, nilai modus sebesar 147,06, dan simpangan baku sebesar 296,613.

Dari pengujian hipotesis yang telah dilakukan, menunjukkan bahwa tidak terdapat pengaruh yang positif dan signifikan persepsi peserta didik mengenai media sosial terhadap sikap toleransi, hal ini berarti hipotesis yang diajukan pada 
bab I ditolak. Oleh karena itu, dapat diinterpretasikan bahwa perubahan pada sikap toleransi tidak terpengaruh dari persepsi peserta didik mengenai media sosial.

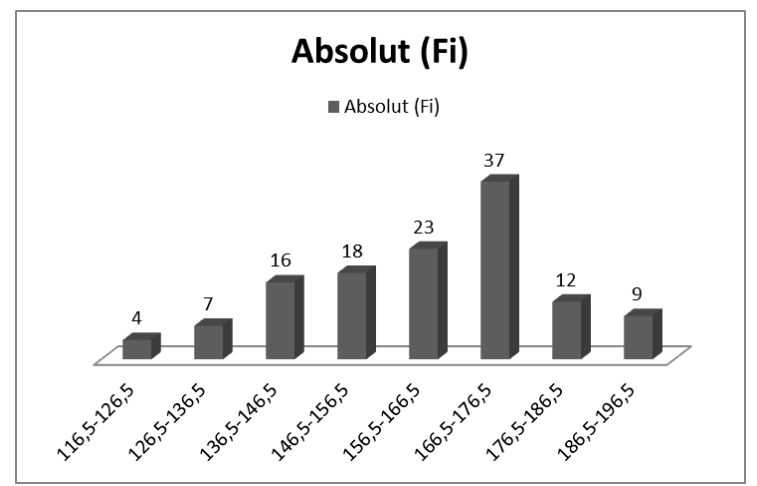

Grafik 2. Frekwensi Tertinggi Peserta Didik Mengenai Sikap Toleransi

Dari grafik di atas dapat diperoleh informasi data yang menunjukkan frekuensi tertinggi sikap toleransi di SMA Bakti Idhata Cilandak, Jakarta Selatan terletak antara 166,5-176,5 dengan frekuensi 37 peserta didik sebesar $29 \%$. Rata-rata skor yang didapat peserta didik yaitu 156,5 , yang terdapat ada interval 156,5-166,5. Adapun nilai modus atau nilai yang sering muncul yaitu 147,50. Artinya variabel persepsi peserta didik mengenai media sosial paling banyak diperoleh bernilai 147,50.

Dari data yang diperoleh, maka dilakukan analisis data yang bertujuan untuk mengetahui keberadaan data dalam pengujian hipotesis penelitian. Perhitungan hipotesis terlebih dahulu dilakukan perhitungan koefisien korelasi dengan menghitung koefisien korelasi antara persepsi peserta didik mengenai media sosial terhadap sikap toleransi.
Pada pengujian ini menggunakan rumus Product Moment sebagai berikut:

$=\frac{r_{x y}}{\sqrt{\left\{n \cdot \sum X^{2}-\left(\sum X\right)^{2}\right\} *\left\{n \cdot \sum Y^{2}-\left(\sum Y\right)^{2}\right\}}}$

Diperoleh $r_{x y}$ hitung sebesar $-0,144$ dan kemudian dibandingkan dengan $r_{x y}$ tabel sebesar $0,195(\mathrm{~N}=126$ dengan taraf signifikan $a=0,05)$ dengan demikian hasil tersebut menunjukkan bahwa $r_{x y}$ hitung $<\mathrm{r}_{\mathrm{xy}}$ tabel.

Tabel 2. Interpretasi Nilai Koefisien Korelasi

\begin{tabular}{ll}
\hline $\begin{array}{l}\text { Interval } \\
\text { Koefisien }\end{array}$ & $\begin{array}{l}\text { Tingkat } \\
\text { Hubungan }\end{array}$ \\
\hline $0,00-0,199$ & Sangat rendah \\
$0,20-0,399$ & Rendah \\
$0,40-0,599$ & Sedang \\
$0,60-0,799$ & Tinggi \\
$0,80-1,00$ & Sangat tinggi \\
\hline \multicolumn{2}{c}{ Sumber: Sugiyono (2004: 184) }
\end{tabular}

Berdasarkan tabel diatas maka dapat disimpulkan bahwa hipotesis ditolak karena tidak terdapat pengaruh yang positif dan signifikan antara persepsi peserta didik mengenai media sosial terhadap sikap toleransi.

Uji signifikansi pada uji t $\quad(\mathrm{N}=126$ dengan taraf signifikan a $=0,05)$ diperoleh $\mathrm{t}_{\text {hitung }}=-0,16204$ dan $\mathrm{t}_{\text {tabel }}=$ 1,65714. Hal ini menunjukkan $t_{\text {hitung }}<$ $\mathrm{t}_{\text {tabel, }}$ maka dapat disimpulkan bahwa tidak terdapat pengaruh positif dan signifikan antara persepsi peserta didik mengenai media sosial terhadap sikap toleransi. 
Selanjutnya Koefisien Determinasi (KD) yang diperoleh hanya sebesar 2,0736\%. Hal ini menunjukkan bahwa sikap toleransi hanya sebesar $2,036 \%$ yang ditentukan dari persepsi media sosial.

Dari pengujian hipotesis yang telah dilakukan, menunjukkan bahwa tidak terdapat pengaruh yang positif dan signifikan persepsi peserta didik mengenai media sosial terhadap sikap toleransi, hal ini berarti hipotesis yang diajukan pada bab I ditolak. Oleh karena itu, dapat diinterpretasikan bahwa perubahan pada sikap toleransi tidak terpengaruh dari persepsi peserta didik mengenai media sosial.

Kesimpulan hasil pengujian hipotesis menunjukkan bahwa hipotesis yang telah ditolak, artinya tidak terdapat pengaruh yang positif dan signifikan persepsi peserta didik mengenai media sosial terhadap sikap toleransi.

Dalam penelitian ini, tidak membuktikan bahwa persepsi peserta didik mengenai media sosial memiliki pengaruh yang positif dan signifikan terhadap sikap toleransi. Melainkan faktor lain yang dapat mempengaruhi sikap toleransi peserta didik seperti lingkungan sosial peserta didik dan pendidikan keluarga peserta didik.

\section{KESIMPULAN}

Berdasarkan hasil penelitian dan pembahasan yang diperoleh dapat diambil kesimpulan bahwa tidak terdapat pengaruh positif dan signifikan persepsi peserta didik mengenai media sosial (Variabel $\mathrm{X}$ ) terhadap sikap toleransi
(Variabel Y) kelas X SMA Bakti Idhata Cilandak, Jakarta Selatan.

Kesimpulan tersebut berdasarkan hasil pengujian hipotesis yang telah dilakukan, dalam pengujian hipotesis dengan menggunakan uji $\mathrm{t}$ yang dapat diketahui $t_{\text {hitung }}=-1,6204$ sedangkan $t_{\text {tabel }}=1,65714$. Setelah dibandingkan, hasilnya thitung $<$ ttabel.

Melalui pengujian hipotesis yang telah dilakukan dapat diketahui bahwa persepsi peserta didik mengenai media sosial tidak memiliki pengaruh yang positif dan signifkan terhadap sikap toleransi.

Berdasarkan hasil penelitian yang telah dipaparkan, maka tidak terbukti bahwa persepsi peserta didik mengenai media sosial memiliki pengaruh yang positif dan signifikan terhadap sikap toleransi. Dengan demikian peneliti menghasilkan kenyataan bahwa persepsi peserta didik mengenai media sosial tidak berpengaruh positif dan signifikan terhadap sikap toleransi. Namun demikian persepsi informasi yang ada dalam media sosial tetap harus dikontrol dan diawasi agar media sosial dapat dimanfaatkan secara positif dan bijak, sehingga tidak menyebabkan adanya sikap untoleransi dikalangan peserta didik.

Penelitian ini diharapkan sebagai sumbangan bagi peserta didik dan guru SMA Bakti Idhata Cilandak, Jakarta Selatan. Untuk dapat meningkatkan sikap toleransi pada peserta didik, melalui persepsi informasi yang ada pada media sosial dengan cara menggunakan media sosial dengan bijak, tidak menyebarkan berita-berita yang dapat memicu adanya konflik sara. 
Bagi guru agar dapat memberikan pendidikan tentang pentingnya sikap toleransi dalam kelangsungan hidup berbangsa dan bernegara. Membimbing peserta didik untuk dapat meningkatkan sikap toleransinya, sehingga peserta didik dapat menunjukkan sikap kesadaran bertoleransi yang baik di lingkungan sekolah, lingkungan keluarga, maupun lingkungan masyarakat.

Bagi sekolah agar mampu memberikan lingkungan yang harmonis melalui pendidikan toleransi dikalangan peserta didik. Karena dalam upaya membentuk sikap toleransi diusia muda maka diharapkan peserta didik dapat hidup berdampingan dengan damai menghadapi perbedaan dikehidupan masyarakat untuk saat ini dan dimasa depan nanti.

Bagi universitas pamulang agar dilakukan penelitian lebih lanjut guna menganalisis data mengenai faktor-faktor lain yang dapat mempengaruhi rendahnya sikap toleransi dikalangan pesertadidik maupun dikalangan masyarakat.

\section{REFERENSI}

Atkinson dkk. (1987). Pengantar Psikolog Jilid II. Batam: Intereks.

Chaplin. (2011). Kamus Lengkap Psikologi, diterjemahkan: Kartini Kartono. Jakarta: PT. Raja Grafindo Persada.

Desmita. (2011). Psikologi Perkembangan Peserta Didik. Bandung: PT. Remaja Rosdakarya.

Drever, J. (2010). Kamus Psikologi. Jakarta: Bina Aksara.
Kartono, K. (1984). Psikologi Umum. Bandung: Alumni.

Muhaimin, I. (2008). Psikologi: Suatu Pengantar. Jakarta: Gramedia Pustaka Utama.

Sarlito, S. W. (2010). Pengantar Psikologi Umum. Jakarta: Rajawali Pers.

Sarwono, S. W. (1976). Pengantar Psikologi. Jakarta: Bulan Bintang.

Slameto. (2010). Belajar dan Faktor-faktor yang Mempengaruhi. Jakarta: Rineka Cipta.

Sugiyono. (2004). Metode Penelitian Kuantitatif Kualitatif dan R\&D. Bandung: Alfabeta.

Walgito, B. (1989). Pengantar Psikologi Umum. Yogyakarta: Andi. 
[ halaman ini sengaja dikosongkan ] 